\title{
MIXTURE STRENGTH CLASS AND SLAB DIMENSIONS' EFFECT ON THE PRECAST CONCRETE PAVEMENT STRUCTURAL PERFORMANCE
}

\author{
AUDRIUS VAITKUS ${ }^{1 *}$, RITA KLEIZIENE'', \\ VIKTORAS VOROBJOVAS', DONATAS ČYGAS ${ }^{2}$ \\ ${ }^{1}$ Road Research Institute, Vilnius Gediminas Technical University, \\ Vilnius, Lithuania \\ ${ }^{2}$ Dept of Roads, Vilnius Gediminas Technical University, \\ Vilnius, Lithuania
}

Received 11 June 2019; accepted 28 June 2019

\begin{abstract}
Mechanical properties and slab dimensions of concrete are the major parameters based on which the performance of concrete pavement structures is predicted. Precast concrete pavement, as one of the most common modular pavement type, is the advanced next-generation technology characterised as high quality, durable, quickly built and easily maintained. The service conditions of precast concrete pavement (traffic loading and environmental effects) are similar to the conventional cast-in-place jointed plain concrete pavement. Thus, the precast concrete pavement structural design is similar to that of jointed plain concrete pavement. There are several concepts for the design of concrete pavement structure. However, they are based on different distress evaluation
\end{abstract}

* Corresponding author. E-mail: audrius.vaitkus@vgtu.lt

Audrius VAITKUS (ORCID ID 0000-0001-5103-9747)

Rita KLEIZIENÉ (ORCID ID 0000-0001-7478-3069)

Viktoras VOROBJOVAS (ORCID ID 0000-0001-9420-0668)

Donatas ČYGAS (ORCID ID 0000-0001-5789-1981) 
and critical stresses estimation methods assuming the slab dimensions that for jointed plain concrete pavement are within the wide joint spacing range from $3.5-6.0 \mathrm{~m}$. The objective of this paper is to analytically evaluate the effect of concrete mixture mechanical properties on the thickness and dimensions of precast concrete pavement slab. Also, define the minimal thickness of precast concrete slab dependent on slab dimensions and concrete mixture mechanical properties elastic modulus and tensile splitting strength. The analysis is based on bearing capacity, performance and fatigue boundary conditions as reported by semi-probabilistic pavement design method Richtlinien für die rechnerische Dimensionierung von Betondecken im Oberbau von Verkehrsflächen RDO Beton 09. Considering that, concrete mixture has significant effects on pavement performance; the composition of concrete was also discussed in this paper. The optimal slab dimensions, concrete layer thickness, and base layer type is suggested in this paper. The outcomes of this analysis apply to the production of precast concrete pavement slabs.

Keywords: concrete mixture design, concrete slab, modular pavement, pavement design, precast concrete pavement (PCP).

\section{Introduction}

Durable, sustainable and easily maintained transport infrastructure is a challenging task for national road administrations and transport agencies. In recent years, the expectations of road users and agencies for the quality of mobility have increased with the development of the research and the innovative engineering solutions. However, many factors lead to inefficient pavement performance, and it is still challenging to meet the expectations. The pavement failure emerges due to underestimated environmental and traffic loading conditions, ineffective pavement design (insufficient layer thickness and inappropriate material selection), delayed maintenance activities. However, the premature defects of pavement surface that significantly decrease pavement service life are mostly related to a poor-quality construction (Chang, Baladi, \& Wolff, 2001). Flexible (asphalt) pavements are the most popular in Europe and North America countries, because of lower cost, faster construction and easier repair compared to rigid (concrete) pavement. However, under specific loading conditions and with longer service life, the well-constructed rigid pavement is a competitive alternative (Breyer \& Kurzfassung, 2004; Kleizienè, Vaitkus, \& Čygas, 2012). The decision-making concept of Life Cycle Cost Analysis (LCCA) is based on the evaluation of long-term economic efficiency between two or more alternative investment options (Walls III \& Smith, 1998). One of the promising alternatives of traditional pavements is the modular pavement technology also known as precast concrete pavement 
(PCP) (Tayabji \& Tyson, 2014; Tayabji, Ye, \& Buch, 2014; Vaitkus, Gražulytė, Kleizienė, Vorobjovas, \& Šernas, 2019).

Kohler, du Plessis, Smith, Harvey, \& Pyle (2007) stated that PCP used for highways, roads, bus lanes, interceptions, parking lots, tunnels, aprons and port pavements as well as repair of traditional concrete pavement. Precast concrete pavement is the advanced next-generation technology characterised as high quality, durable, quickly built and easily maintained. Precast concrete pavement technology has been investigated, produced, constructed and maintained over the past 40 years in different countries and continents. However, the scientific attention and engineering innovations were developed nowadays, when the need for fast, durable pavement construction and repair appeared. The advantages of PCP compared to the cast-in-place jointed plain concrete pavement (JPCP) are as follows (Kohler, du Plessis, Smith, Harvey, \& Pyle, 2007; Tayabji \& Tyson, 2014):

- an improved and consistent quality of concrete;

- ensured steady conditions of concrete curing;

- minimised influence of weather conditions during production;

- reduced traffic delays after installation;

- reduced risk of joint ravelling.

There are several types of PCP with slab dimensions, reinforcement and jointing (Vaitkus, Gražulytė, Kleizienè, Vorobjovas, \& Šernas, 2019): precast pre-stressed concrete pavement, JPCP, incrementally connected PCP. Design of PCP is based on the assumption that the overall service conditions of PCP (traffic loading and environmental effects) will be similar to the cast-in-place JPCP (Smith \& Snyder, 2017; Tayabji \& Tyson, 2014). Thus, usually, the thickness of PCP is designed in agreement with the traditional concrete pavement design procedures. However, during the production of PCP, the quality is controlled more accurately to assure high reliability compared to the cast-in-place JPCP and therefore, the panel design thickness is reduced. The concrete pavement performance is affected by load weight, driving speed (frequency), stress level (ratio), number of load cycles, concrete pavement slab dimensions and thickness (size effect), load transfer at joint, mechanical properties of concrete and slab.

Concrete pavement joint spacing is determined taking into account the following factors: slab thickness, mechanical and physical properties of concrete (coefficient of thermal expansion, strength and elasticity), foundation bearing capacity, and environmental conditions. Joints have to be designed close enough to prevent curling stress accumulation. Slab curling occurs cyclically: with increasing temperature at daytime, the slab curls downward, and with decreasing temperature, at night it curls upwards. The slab edge-stress due to temperature is a function of 
concrete thermal expansion, the temperature difference between the top and the bottom of slab, and correction factor determined by the ratio of slab length $(L)$ and radius of relative stiffness $(I)$ (Bradbury, 1938). The is above 4.4 to avoid transverse cracking of slab (American Concrete Institute..., 2002). Even though the stress cycles due to curling are much fewer than to loading joint, the coefficient of thermal expansion of concrete impacts the performance and serviceability of pavement structure (Delatte, 2008).

The concrete pavement of road or runway structures operates under repetitive cyclic loading conditions. However, usual standard concrete tests and design procedures evaluate concrete performance under constant compressive load and resistance to fatigue is determined based on a probabilistic design concept evaluating the reliability. The resistance to fatigue of concrete pavement is mainly subjected to dynamic or static flexural strength of concrete. The fatigue performance of concrete was investigated by many researchers (Disfani, Arulrajah, Haghighi, Mohammadinia, \& Horpibulsuk, 2014; Goel, Singh, S. P., \& Singh, P. 2012; Graeff, Pilakoutas, Neocleous, \& Peres, 2012; Li, Zhang, \& Ou, 2007; Mai, Le-Corre, Forêt, \& Nedjar, 2012; Zanuy, de la Fuente, \& Albajar, 2007) and fatigue is mostly determined using probabilistic methods and $S$ - $N$ curves (providing the number of cycles to failure of a constant amplitude).

The objective of this paper is to define the minimal thickness of precast concrete slab dependent on slab dimensions and concrete mixture mechanical properties, elastic modulus and tensile strength. The tasks of this research involve:

- analysis of concrete pavement design methods;

- analysis of concrete mixture mechanical properties;

- study on the effect of concrete mechanical properties on slab dimensions;

- determine the optimal thickness and slab dimensions for precast cement concrete pavement.

\section{Design methods for concrete pavement structure}

\subsection{The concept of concrete pavement design}

Concrete pavement design starts with a definition of parameters, like the level of structural performance, target service life, concrete properties (durability, strength, rigidity, and shrinkage) to achieve optimum performance. Currently, concrete pavement thickness design 
is a semi-probabilistic analytical method based on mechanical and empirical data (Jung \& Zollinger, 2007; Villaret, Kiehne, Riwe, \& Villare, 2008; Wojtkiewicz, Khazanovich, Gaurav, \& Velasquez, 2010). The principle is mainly based on damage (Minner) hypothesis that pavement response under design conditions has to be less than limit (boundary condition) response under the same traffic load and environmental conditions. The three distress types of JPCP are evaluated in the Mechanistic-Empirical Pavement Design Guide (MEPDG) (American Association of State..., 2008, 2015):

- mean transverse joint faulting - is a result of a combination of repetitive load cycles of moving heavy axles, load transfer at joint, free moisture beneath the slab, permanent deformation of base/ subbase, and upward curling of the slab. Khazanovich, Darter, \& $\mathrm{Yu}$ (2004) proposed a JPCP design algorithm based on transverse joint faulting (Figure 1);

- bottom-up and top-down transverse cracking - is a result of fatigue damage of repeated traffic loading near the longitudinal edge of the slab at the high positive (bottom-up) and high negative (top-down) temperatures;

- smoothness - is a function of the initial profile change over time due to damage (transverse cracking, joint with sapling and joint faulting) percentage accumulation.

The damage under critical locations in the pavement subjected to influence of load and temperature are calculated based on deflections (Khazanovich, Darter, \& Yu, 2004), deflection moments (Richtlinien für die rechnerische Dimensionierung von Betondecken im Oberbau von Verkehrsflächen RDO Beton 09) or neural network analysis (American Association of State..., 2008, 2015). The critical responses in MEPDG are calculated using neural network analysis based on inputs of slab and base course combined into equivalent stresses of loads and temperature/moisture gradients, and friction between slab and base. The pavement response (stress and strain), traffic load and temperature are calculated under theoretical assumptions such as:

- the shape of concrete plate - rectangular;

- material behaviour - linear elastic;

- Bernoulli hypothesis validation;

- load effect on an unloaded plate - no pre-deformation;

- feasibility of joint edges - none;

- state of tension - uniaxial;

- normal stresses in the plate are not considered.
Audrius Vaitkus, Rita Kleizienè, Viktoras Vorobjovas, Donatas Čygas

Mixture Strength

Class and Slab Dimensions' Effect on the Precast Concrete Pavement Structural Performance 


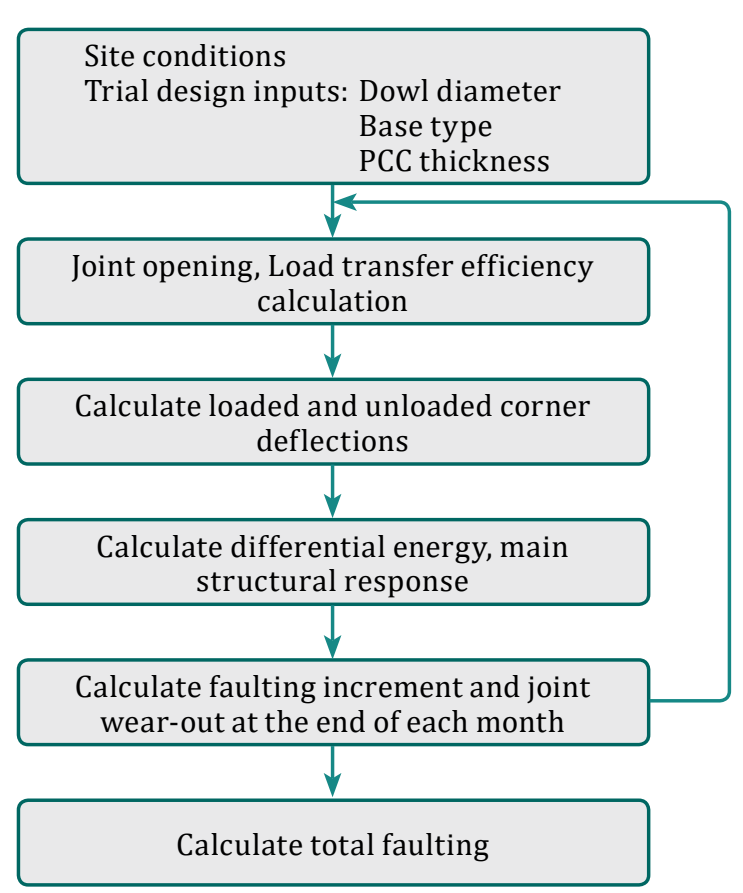

Figure 1. Concrete pavement design based on transverse joint faulting (Khazanovich, Darter, \& Yu, 2004)

\subsection{Analysis of concrete mixture properties}

The design of concrete mixture has to be evaluated by analysing economic, technical, mechanical (strength needed for design), workability and durability factors. The proportions of individual constituents of the concrete mixture are determined by prescriptive or performance-based design methods. Concrete mixture design starts with selecting the following parameters (Kosmatka, Kerkhoff, \& Panarese, 2002): strength, minimum cement content or maximum water-cement ratio, the nominal maximum size of aggregate, air content, and suitable slump. The required properties of fresh concrete depend on the type of construction, placing and transporting technologies. The required properties of hardened concrete are specified by the design of concrete pavement structure. Standard cement concrete classes used for pavement design according to the RDO Beton 09 are presented in Table 1 . The normal strength concrete is used for construction of road pavements with additional requirements for fatigue, thermal expansion, and resistance to scaling and de-icing mixtures. Typical specifications of 
paving concrete are (Kosmatka, Kerkhoff, \& Panarese, 2002; Tayabji, Ye, \& Buch, 2013; TL Beton-StB 07 Technische Lieferbedingungen für Baustoffe und Baustoffgemische für Tragschichten mit hydraulischen Bindemitteln und Fahrbahndecken aus Beton;):

- fresh concrete mixture:

- water-cement ratio (0.37-0.45);

- air content (minimum air voids in fresh concrete with a maximum $8 \mathrm{~mm}$ aggregate size $-5.5 \%$, and with $32 \mathrm{~mm}$ or $22-4.0 \%$ );

- aggregate gradation (optimal aggregate gradation results in less need for cement paste);

- slump for pavements and slabs (75-25 mm).

- hardened concrete:

- flexural (4.5-5.2 MPa) strength after 28 days;

- compressive (27.5-40.0 MPa) strength after 28 days;

- durability (resistance to fatigue, alkali-silica reactivity, the influence of sulphate, D-cracking, scaling).

Table 1. Standard cement concrete classes used for pavement design according to the Richtlinien für die rechnerische Dimensionierung von Betondecken im Oberbau von Verkehrsflächen RDO Beton 09

\begin{tabular}{|c|c|c|c|c|}
\hline \multirow{3}{*}{$\begin{array}{l}\text { Layer } \\
\text { of } \\
\text { pavement } \\
\text { structure }\end{array}$} & \multicolumn{2}{|c|}{ Concrete class for road pavement } & \multirow{3}{*}{ 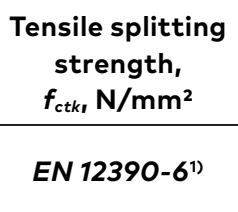 } & \multirow{3}{*}{$\begin{array}{c}\begin{array}{c}\text { Tensile elasticity } \\
\text { modulus, } \\
E_{\text {ctm, }} \mathrm{MPa}\end{array} \\
\text { STR 2.05.05:2005 }\end{array}$} \\
\hline & \multicolumn{2}{|c|}{ Class of } & & \\
\hline & $\begin{array}{l}\text { environmental } \\
\text { properties }\end{array}$ & $\begin{array}{l}\text { mechanical } \\
\text { properties }\end{array}$ & & \\
\hline \multirow{9}{*}{$\begin{array}{c}\text { Concrete } \\
\text { wearing } \\
\text { (top) }\end{array}$} & \multirow{9}{*}{$\begin{array}{l}X M 2 \\
\text { and } \\
X F 4^{3)}\end{array}$} & StC $30 / 37-3.0$ & 3.0 & 37000 \\
\hline & & StC $30 / 37-3.3$ & 3.3 & 39000 \\
\hline & & StC $30 / 37-3.7$ & 3.7 & 41000 \\
\hline & & StC $35 / 45-3.3$ & 3.3 & 39000 \\
\hline & & StC $35 / 45-3.7$ & 3.7 & 41000 \\
\hline & & StC $35 / 45-4.0$ & 4.0 & 42000 \\
\hline & & StC $40 / 50-4.0$ & 4.0 & 42000 \\
\hline & & StC $40 / 50-4.3$ & 4.3 & 43000 \\
\hline & & StC $40 / 50-4.6$ & 4.6 & 44000 \\
\hline \multirow{4}{*}{$\begin{array}{c}\text { Concrete } \\
\text { base }\end{array}$} & \multirow{4}{*}{$\begin{array}{l}\text { No } \\
\text { requirement }\end{array}$} & StC $25 / 30-2.4$ & 2.4 & 34000 \\
\hline & & StC $25 / 30-2.7$ & 2.7 & 35000 \\
\hline & & StC $25 / 30-3.0$ & 3.0 & 37000 \\
\hline & & StC $25 / 30-3.3$ & 3.3 & 39000 \\
\hline
\end{tabular}

Note: ${ }^{1}$ EN 12390-6 Testing Hardened Concrete - Part 6: Tensile Splitting Strength of Test Specimens; ${ }^{2}$ STR 2.05.05:2005 Design of Concrete and Reinforced Concrete Constructions; ${ }^{3}$ EN 206 Concrete - Part 1: Specifications, Performance, Production and Conformity.
Audrius Vaitkus, Rita Kleizienè, Viktoras Vorobjovas, Donatas Čygas

Mixture Strength

Class and Slab Dimensions' Effect on the Precast

Concrete Pavement

Structural

Performance 


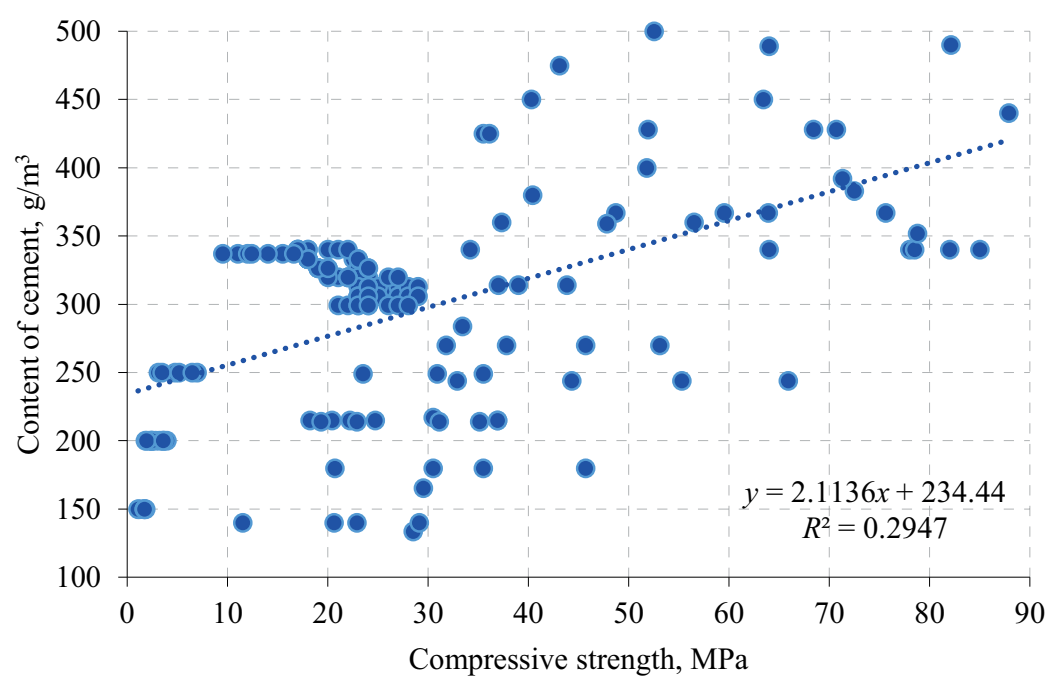

a) comparison of cement content influence on compressive strength

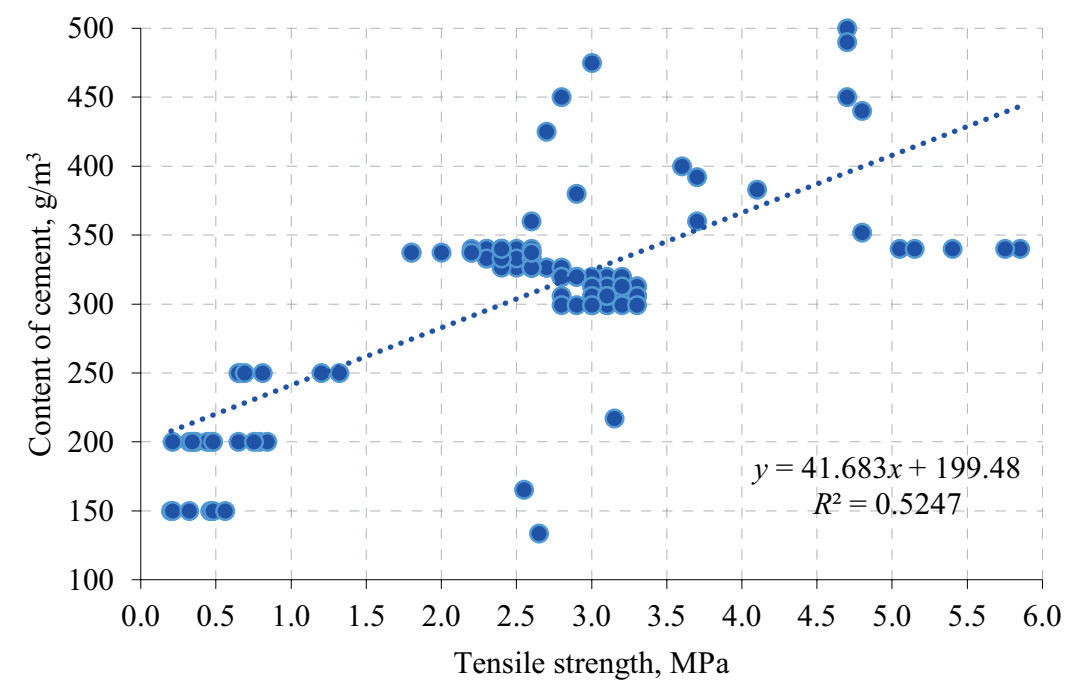

b) comparison of cement content influence on tensile strength 


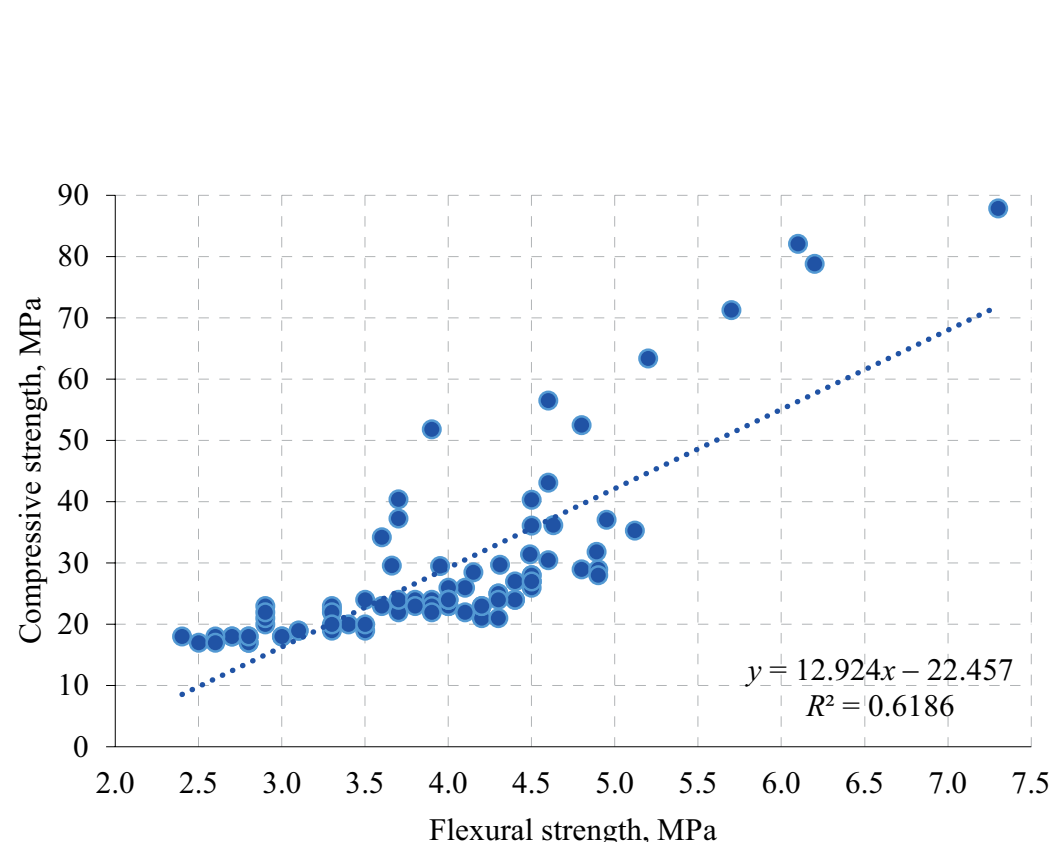

c) comparison of compressive and flexural strength

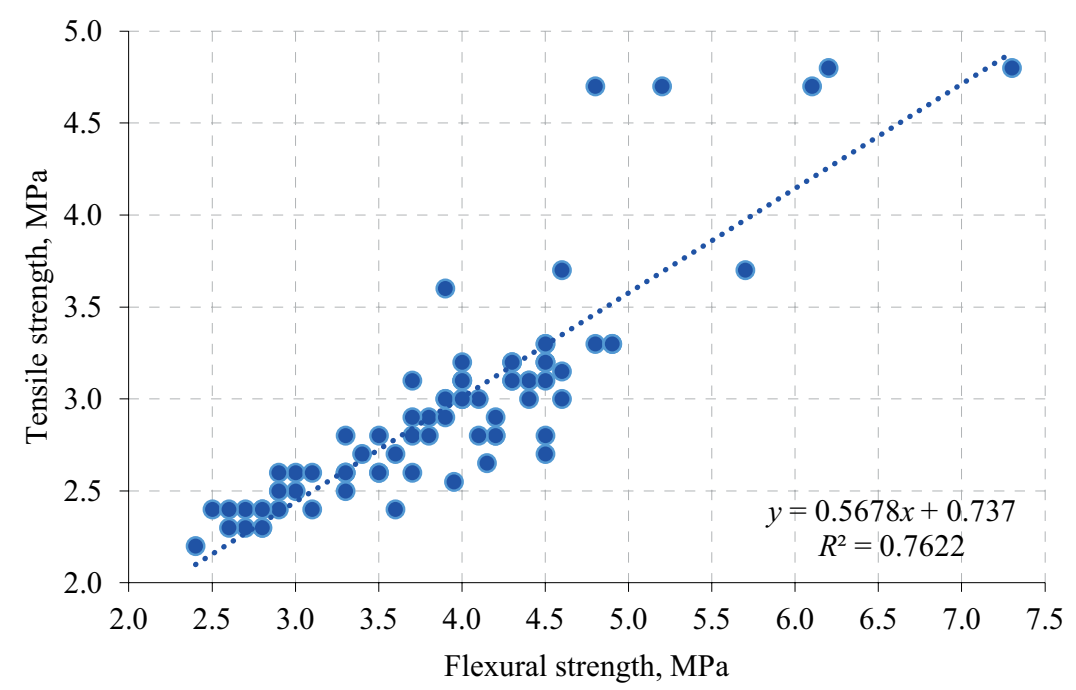

d) comparison of tensile and flexural strength

Figure 2. Summary of the analysis of concrete mixture influence on mechanical properties (Hesami, Ahmadi, \& Nematzadeh, 2014; Huang, Wu, Shu, \& Burdette, 2010; Ibrahim, Mahmoud, Yamin, \& Patibandla, 2014; Isaia, Gastaldini, \& Moraes, 2003; Jalal, Pouladkhan, Harandi, \& Jafari, 2015; Naik, Ramme, \& Tews, 1994; Nehdi, Pardhan, \& Koshowski, 2004; Phoo-ngernkham, Chindaprasirt, Sata, Hanjitsuwan, \& Hatanaka, 2014; Rangelov, Nassiri, Haselbach, \& Englund, 2016; Shannag, 2000)
Audrius Vaitkus, Rita Kleizienè, Viktoras Vorobjovas, Donatas Čygas

Mixture Strength

Class and Slab Dimensions' Effect on the Precast Concrete Pavement Structural Performance 
Flexural strength (or modulus of rupture) of concrete is the basic input in the design of concrete pavements and slabs (Kosmatka, Kerkhoff, \& Panarese, 2002). Since the compressive strength test is easier to perform, the flexural strength assumed from the index and empirical relationship. Wood (1992) stated that the flexural strength of normal-weight concrete could be approximated to 0.7-0.8 times the square root of the compressive strength in MPa. An extended review of the studies of several researchers allowed for determining correlations between the content of cement and mechanical properties (Figure 2 and Table 2). The measurements of other researchers show that there is a weak relation between cement content and compressive and tensile strength. However, with a cement content of $340-360 \mathrm{~kg} / \mathrm{m}^{3}$, optimal composition and additives the improve mechanical properties significantly (compressive strength above $78 \mathrm{MPa}$, and tensile strength above 4.8 MPa. Nazari and Riahi (2012) determined that adding nano $\mathrm{SiO}_{2}$ increases concrete compressive, split tensile and flexural strength up to $4 \%$ compared to the concrete mixture without additives (Nazari \& Riahi, 2012). Goel, Singh, S. P., \& Singh, P. (2012) investigated the influence of steel fibre on the fatigue properties of concrete and determined that adding $1.0 \%$ of steel fibre allows increasing fatigue strength by $76 \%$ and static flexural strength by $73 \%$ (Goel, Singh, S. P., \& Singh, P. (2012). Klcriber (1982) stated that the water-cement ratio in concrete affects the flexural fatigue behaviour of unreinforced concrete. Naik, Ramme, Kraus, \& Siddique (2003) and Naik, Ramme, \& Tews (1994) investigated the performance of high-volume fly ash cast-in-place plane concrete pavement after 14 years of service (Naik, Ramme, \& Tews, 1994). Researchers stated a good performance of fly ash used in concrete pavement in terms of density, compressive strength, resistance to chloride penetration and salt scaling (Naik, Ramme, Kraus, \& Siddique, 2003). Thus, the use of the concrete mixture with improved mechanical properties will allow to increase durability and performance of pavement or to assure the same performance with a thinner layer of concrete pavement. 


\subsection{Joints, dimensions and reinforcement of concrete pavement}

Concrete pavement joint function includes control of cracking, provision of load transfer, isolation of structures that behave differently, and provision of the lane delineation (Federal Highway Administration, 2019). Jointing of precast concrete panels has to be designed in longitudinal and transversal directions, thus assuring that percentage of the load to be transferred across the joint is $100 \%$.

The spacing of transverse and longitudinal contraction joints depends on material and environmental conditions. Joint spacing selected from empirical data or calculated evaluating the relationship between the maximum panel length $(L)$ and the radius of relative stiffness $(l)$. The recommended ratio between slab length, pavement thickness and Effective Modulus of Subgrade Reaction ( $k$ value) is presented in Figure 3. Smith, Peshkin, Darter, Mueller, \& Carpenter (1990) stated that joint faulting and transverse cracking appear more frequently when joint spacing is above $5.5 \mathrm{~m}$ (Smith, Peshkin, Darter, Mueller, \& Carpenter, 1990). In ZTV Beton-StB 07 Zusätzliche Technische Vertragsbedingungen und Richtlinien für den Bau von Tragschichten mit hydraulischen Bindemitteln und Fahrbahndecken aus Beton, transversal contraction joints are constructed in the same locations as a notch in the hydraulically bound base layer (HBBL) with not greater than $5 \mathrm{~m}$ spacing. Federal Highway Administration (2019) stated good performance practice of JPCR with panels of $4.6 \mathrm{~m}$ in length and $3.7 \mathrm{~m}$ in width. The ratio between the slab width and length, according to American Association of State... (1993) should not exceed 1.25, and according to Federal Highway Administration (2019) should not exceed 1.5 .

Properly designed and maintained contraction joints eliminated the need for expansion joints except at connections with structures and around manholes (ZTV Beton-StB 07; Mallick \& El-Korchi, 2013). The ratio between maximum dimension and thickness of the slab according to ZTV-Beton StB 07 should be less than 25 times and according to Federal Highway Administration (2019) within 18-24 times, and if this ratio is not assured the reinforcement has to used. According to Smith and Snyder (2017), precast panels should be reinforced to ensure the handling and transportation conditions. During the production of the slab and concrete hardening, it is necessary to assure the precast concrete slab resistance to warping.

The dowel bars or dowel-type elements are required for the joint plane concrete pavement to ensure the load transfer across the transversal joint. Dowel bars reduce slab deflection by nearly $50 \%$
Audrius Vaitkus, Rita Kleiziene, Viktoras Vorobjovas, Donatas Čygas

Mixture Strength

Class and Slab

Dimensions' Effect on the Precast

Concrete Pavement

Structural

Performance 


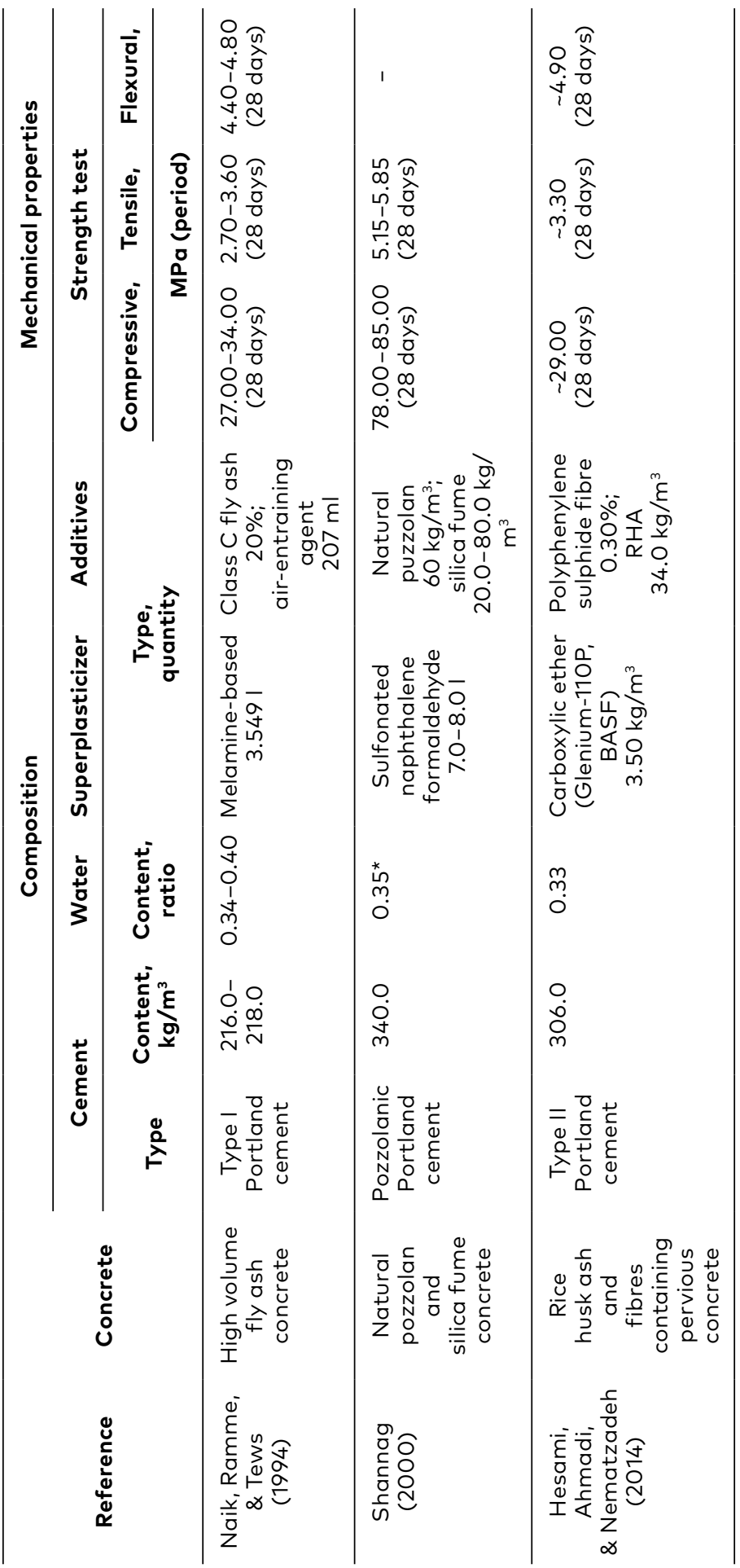




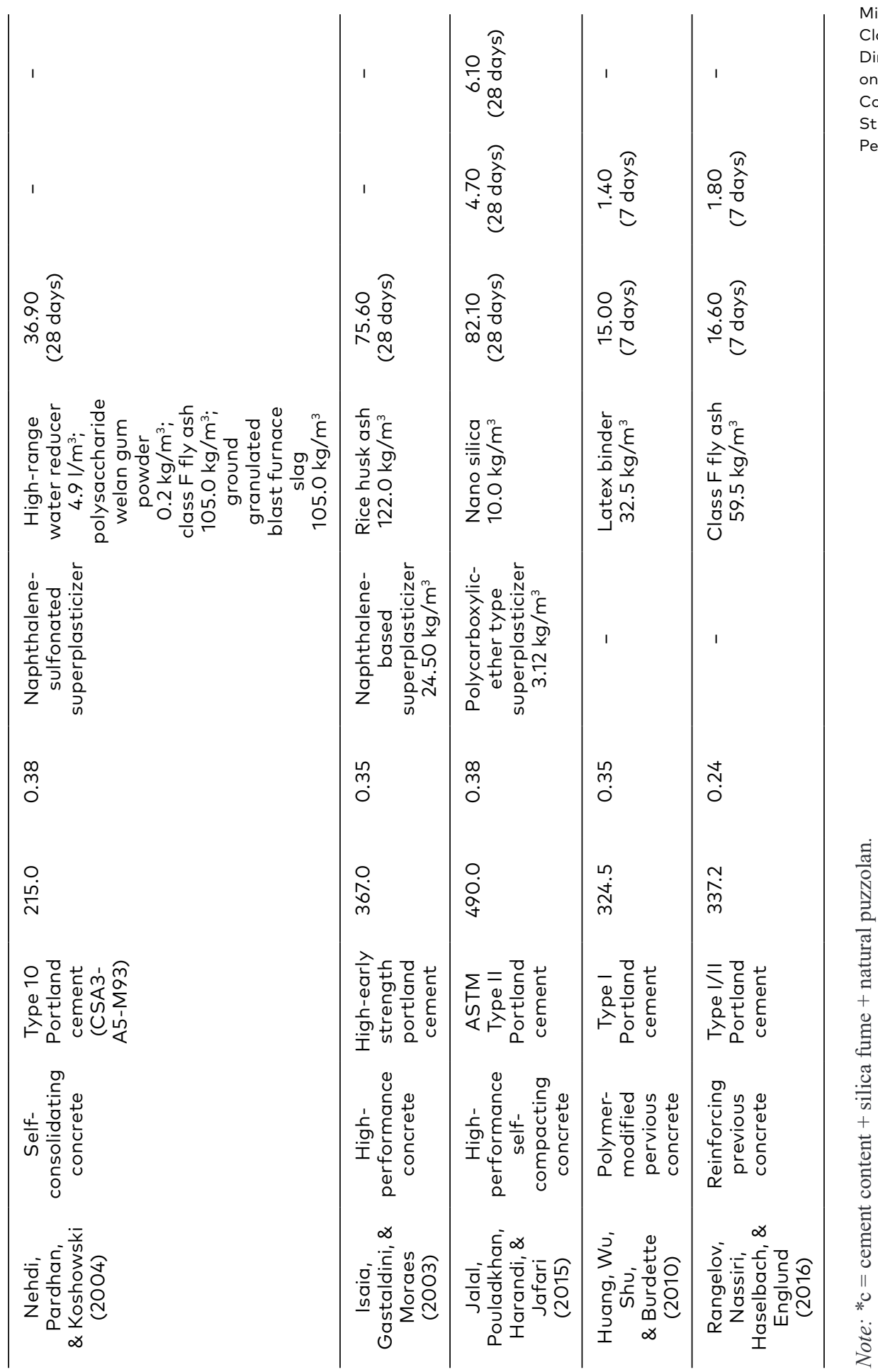

Mixture Strength

Class and Slab

Dimensions' Effect on the Precast

Concrete Pavement

Structural

Performance 
(Darter, Hall, \& Kuo, 1995). Table 3 gives a review of the dimensions and spacing of dowels. Additional considerations for PCP are to analyse of:

1. load transfer at joint;

2. base layer conditions;

3. temperature-related curling/warping and width of the panel (transverse joint spacing);

4. expansion joint width and spacing.

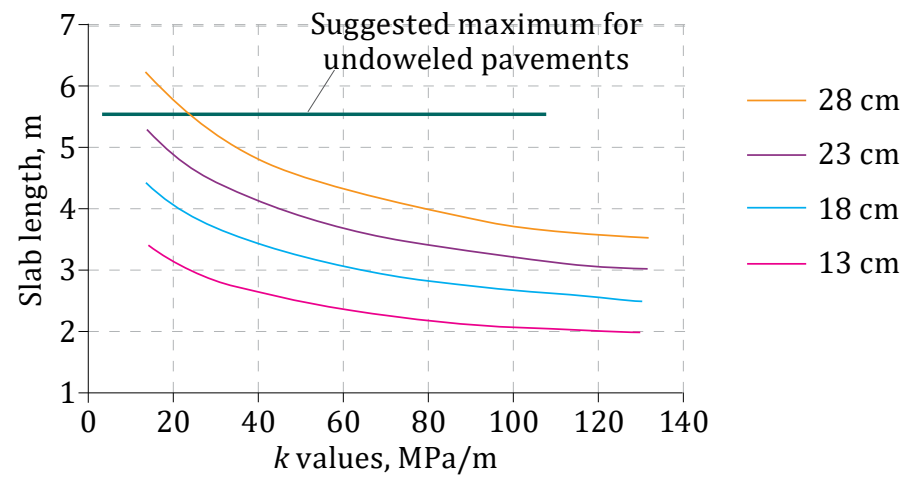

Figure 3. Recommended ratio between slab length and pavement thickness (American Concrete Institute..., 2002)

Table 3. Review of dimensions and spacing of dowels

\begin{tabular}{|c|c|c|c|c|}
\hline $\begin{array}{l}\text { Thickness of slab, } \\
\mathrm{mm}\end{array}$ & $\begin{array}{l}\text { Dowel diameter, } \\
\mathrm{mm}\end{array}$ & $\begin{array}{l}\text { Length, } \\
\mathrm{mm}\end{array}$ & $\begin{array}{c}\text { Dowel spacing, } \\
\mathrm{mm}\end{array}$ & Reference \\
\hline $152-178$ & 20 & 460 & 305 & $A C 150 / 5320-6 F$ \\
\hline 191-305 & 25 & 460 & 305 & $\begin{array}{c}\text { Airport Pavement } \\
\text { Desian }\end{array}$ \\
\hline $318-406$ & 30 & 510 & 380 & and Evaluation \\
\hline $419-508$ & 40 & 510 & 460 & \\
\hline $521-601$ & 50 & 510 & 460 & \\
\hline below 200 & \multicolumn{3}{|c|}{ Dowels are not required } & American Concrete \\
\hline 200 & 32 & 450 & 300 & $\begin{array}{c}\text { Institute... } \\
(2002)\end{array}$ \\
\hline 250 & 32 & 450 & 300 & \\
\hline 280 & 38 & 450 & 300 & \\
\hline 300 & 38 & 450 & 300 & \\
\hline 350 & 44 & 500 & 300 & \\
\hline no less than 400 & 50 & 600 & 450 & \\
\hline 200 & 25 & 500 & 500 & ZTV-Beton \\
\hline $230-270$ & 25 & 500 & 250 & StB 07 \\
\hline
\end{tabular}




\section{The subject of experiment and methodology}

The slab thickness and dimensions were calculated corresponding to the boundary conditions based on the semi-probabilistic analysis detailed in RDO Beton 09 to evaluate the effect of mechanical properties of the concrete mixture on the PCP. Boundary conditions of the moment used in concrete pavement design are presented in Table 4 and Figure 5. In this study three-pavement performance conditions at two locations in the slab, defined using probabilities to failure models, were evaluated to determine concrete slab dimensions (Table 4):

- boundary conditions of bearing capacity - represent structural failure distress of concrete pavement (transversal cracking and joint faulting);

- the boundary condition of performance - represent surface failure distress of concrete pavement (roughness);

- the boundary condition of fatigue resistance - represent the bearing capacity for the accumulation of stresses occurring in the long term of repetitive loading.

The bending moments are calculated for all boundary conditions at the centre of the longitudinal and transversal joint. Locations for the estimation of bending moment in the slab are presented in Figure 4.

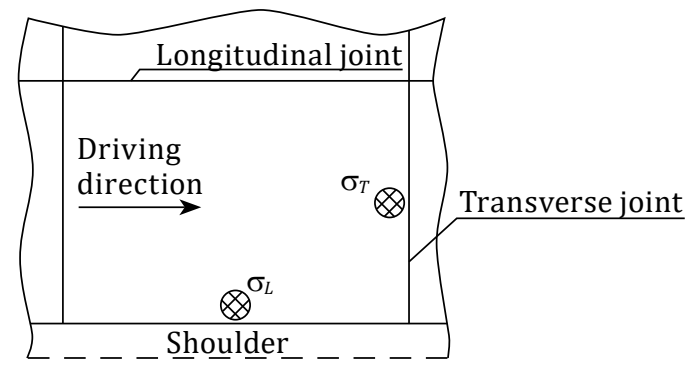

Figure 4. Locations for the estimation of bending moment in the slab

Table 4. Boundary conditions for concrete pavement design

\begin{tabular}{lcc}
\hline \multirow{2}{*}{ Boundary conditions } & \multicolumn{2}{c}{ Bending moment } \\
\cline { 2 - 3 } & $\begin{array}{c}\text { At longitudinal joint }(L) \\
\text { at slab centre of the edge }\end{array}$ & $\begin{array}{c}\text { At transverse joint }(T) \\
\text { at slab centre }\end{array}$ \\
\hline Bearing capacity (BCBC) & $M_{R, B C B C, L} \geq M_{E, B C B C, L}$ & $M_{R, B C B C, T} \geq M_{E, B C B C, T}$ \\
Performance (BCPC) & $M_{R, B C P C, L} \geq M_{E, B C P C, L}$ & $M_{R, B C P C, T} \geq M_{E, B C P C, T}$ \\
Fatigue resistance (F) & $M_{R, F, L} \geq M_{E, F, L}$ & $M_{R, F, T} \geq M_{E, F, T}$ \\
\hline
\end{tabular}




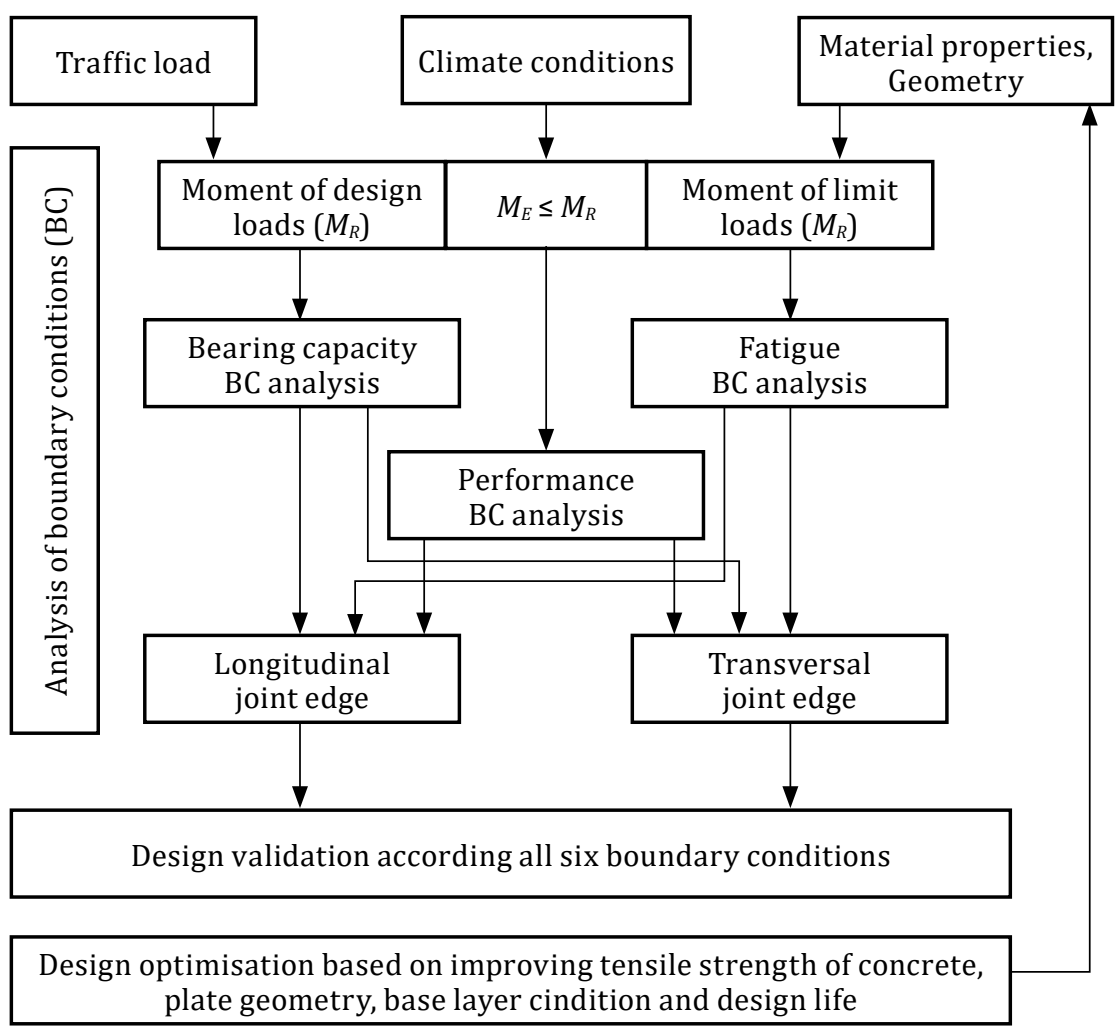

Figure 5. Concrete pavement design based on boundary conditions of design moment $M_{E}$ and limit moment $M_{R}$ (Villaret, Kiehne, Riwe, \& Villare, 2008)

The basis of concrete pavement design is the assurance that the limit (threshold) bending moments $M_{R}$ are no less than the design bending moments $M_{E}$ in all analysis cases. The limit bending moments $M_{R}$ mainly depending on the slab thickness and strength, which are calculated according to the Eq. (1).

$$
M_{R}=0.167 h_{d}^{2} f_{d},
$$

where $M_{R}$ - limit bending moment, $\mathrm{Nmm} / \mathrm{mm} ; h_{d}$ - thickness of the concrete surface, $\mathrm{mm} ; f_{d}$ - calculated strength, $\mathrm{N} / \mathrm{mm}^{2}$, according to the adjustment factor $m_{b}$ and primal calculated strength $f_{d}^{0}$.

Based on analysis cases the calculated strength $f_{d}$ varies depending on analysis type and primal calculated strength $f_{d}^{0}$ (Table 5), which directly corresponds to the characteristic tensile splitting strength $f_{\text {ctk }}$ of the concrete and safety coefficients to evaluate reliability. For the limit bending moment estimation under boundary condition of fatigue resistance (longitudinal joint $M_{R, F, L}$ and transverse joint $M_{R, F, T}$ ) the design load $A$ of equivalent $10 \mathrm{t}$ axles over the design life is evaluated with 
fatigue coefficient $\gamma_{c, F}$, which depending on the load transfer factor $\gamma_{q}$ and is calculated according to the Eq. (2).

$$
\gamma_{c, F}=0.15 \log \left(\gamma_{q} A\right)+0.748 \mathrm{e}^{-0.1365},
$$

where $\gamma_{c, F}$ - fatigue coefficient, which evaluates the design load of equivalent $10 \mathrm{t}$ axles over the design life; $A$ - number of equivalent $10 \mathrm{t}$ weight axial load over the design life, millions of passes; $\gamma_{q}$ - load transfer factor, according to Table 6 .

Table 5. The factors for calculated strength estimation based on the analysis type of pavement performance conditions

\begin{tabular}{lcc}
\hline \multirow{2}{*}{$\begin{array}{l}\text { Analysis type of pavement performance } \\
\text { conditions }\end{array}$} & \multicolumn{2}{c}{ Coefficients } \\
\cline { 2 - 3 } & $\boldsymbol{m}_{b}$ & $\boldsymbol{f}_{d}^{0}$ \\
\hline $\begin{array}{l}\text { Boundary conditions of bearing capacity } \\
\text { and of performance }\end{array}$ & 1.0 & $\frac{f_{c t k}}{k_{b t}}$ \\
$\begin{array}{l}\text { The boundary condition of fatigue } \\
\text { resistance }\end{array}$ & $\frac{1}{\gamma_{c, F}}$ & $\frac{k_{b n} f_{c t k}}{k_{b t}}$ \\
\hline
\end{tabular}

Table 6. Load transfer factors $\gamma_{q}$

\begin{tabular}{ccc}
\hline $\begin{array}{c}\text { Slab width, } \\
\mathrm{m}\end{array}$ & $\begin{array}{c}\text { Longitudinal joint } \\
\gamma_{q, L}\end{array}$ & $\begin{array}{c}\text { Transverse joint } \\
\gamma_{q, T}\end{array}$ \\
$>$ 2.00 to 2.50 & 0.400 & 0.90 \\
$>$ 2.50 to 3.00 & 0.180 & 0.80 \\
$>$ 3.00 to 3.50 & 0.140 & 0.70 \\
$>$ 3.50 to 3.75 & 0.018 & 0.70 \\
$>3.75$ to 4.50 & 0.008 & 0.60 \\
\hline
\end{tabular}

The design bending moments $M_{E}$ that occur in the slab from design load or temperature application, are calculated as a sum of design moments caused by traffic load $M_{E V}$ and by temperature $M_{E T}$.

$$
\begin{gathered}
M_{E}=M_{E V}+M_{E T} \\
M_{E V}=m_{b L} m_{b d} F_{d} 1000\left[0.55 \lg \left(\frac{I_{v}}{b}\right)+0.1 \frac{b}{I_{v}}-0.011\right] \\
M_{E T}=\alpha_{c T} \gamma_{t o t} E_{c t m} \frac{h_{m}^{3} m_{t_{1}} m_{t_{2}} m_{t_{3}} \delta_{t}}{12}
\end{gathered}
$$

where factors used for the calculation of $M_{E V}, M_{E T}$ are given in $R D O$ Beton 09.
Audrius Vaitkus, Rita Kleizienè, Viktoras Vorobjovas, Donatas Čygas

Mixture Strength

Class and Slab Dimensions' Effect on the Precast

Concrete Pavement

Structural

Performance 
The slab design of PCP for the evaluation of mechanical properties of the concrete mixture was carried out combining RDO Beton 09 and KPT SDK 19 Automobiliu keliu standartizuotu dangu konstrukciju projektavimo taisykles technical regulations. The design load calculated assuming the annual average daily traffic (AADT, vpd) is 10000 heavy vehicles per day, the design life of 30 years, with $3 \%$ of annual growth of AADT. The design of the national road, where the allowed driving speed of $90 \mathrm{~km} / \mathrm{h}$. Thus, the estimated design load $A$ for the service life is 76 million of equivalent $10 \mathrm{t}$ weight of standard axle load. The summary of design input data and coefficients are presented in Table 7. The input of variables for concrete pavement design and estimation of slab thickness and dimensions are presented in Table 8. The reinforcement was provided with a diameter of $25 \mathrm{~mm}$ and 500 length dowels placed with $250 \mathrm{~mm}$ spacing to ensure the load transfer efficiency at PCP slab joints.

Table 7. Summary of design input data and coefficients

\begin{tabular}{lccc}
\hline \multicolumn{1}{c}{ Name } & Symbol & Unit & Inputs \\
\hline Design year, & $N$ & & 30 \\
Annual average daily traffic of heavy vehicles & AADT(SV) & vpd & 10000 \\
Coefficient of axle numbers & $f_{A}$ & - & 3.90 \\
Single axles & & axles per day & 39000 \\
Coefficient of axle load & $q_{B m}$ & - & 0.20 \\
Coefficient of lane numbers & $f_{1}$ & - & 0.50 \\
Coefficient of lane width & $f_{2}$ & - & 1.10 \\
Coefficient of longitudinal slope & $f_{3}$ & - & 1.02 \\
Annual traffic growth & $p$ & - & 0.03 \\
Coefficient of annual traffic growth & $f_{z}$ & - & 1.586 \\
Design equivalent single axle load (ESAL) & $A$ & mln. & 75.986 \\
\hline
\end{tabular}


Table 8. Concrete pavement design variables

\begin{tabular}{|c|c|c|c|c|c|c|}
\hline \multirow{3}{*}{$\begin{array}{l}\text { Design } \\
\text { code }\end{array}$} & \multirow{3}{*}{$\begin{array}{c}\text { Pavement } \\
\text { base } \\
\text { layer } \\
\text { type }\end{array}$} & \multirow{3}{*}{$\begin{array}{l}\text { Concrete } \\
\text { class }\end{array}$} & \multirow{3}{*}{$\begin{array}{c}\begin{array}{c}\text { Tensile } \\
\text { splitting } \\
\text { strength }\end{array} \\
\begin{array}{c}\boldsymbol{f}_{\text {ctk, }} \\
\mathrm{N} / \mathrm{mm}^{2}\end{array} \\
\end{array}$} & \multirow{3}{*}{$\begin{array}{c}\begin{array}{c}\text { Tensile } \\
\text { elasticity } \\
\text { modulus }\end{array} \\
\begin{array}{c}E_{c t m} \\
G P a\end{array} \\
\end{array}$} & \multicolumn{2}{|c|}{ Concrete slab } \\
\hline & & & & & length & width \\
\hline & & & & & $\begin{array}{l}L, \\
\mathrm{~m}\end{array}$ & $\begin{array}{l}W \\
\mathrm{~m}\end{array}$ \\
\hline $1-1$ & Crushed stone & $\mathrm{C} 30 / 37$ & 3.7 & 41.0 & 4.60 & 4.10 \\
\hline $1-2$ & Crushed stone & C35/45 & 4.0 & 42.0 & 4.60 & 4.10 \\
\hline $1-3$ & Crushed stone & $\mathrm{C} 4 \mathrm{O} / 5 \mathrm{O}$ & 4.6 & 44.0 & 4.60 & 4.10 \\
\hline $1-4$ & Crushed stone & $\mathrm{C} 40 / 50$ & 4.7 & 46.0 & 4.60 & 4.10 \\
\hline $1-5$ & Crushed stone & $\mathrm{C} 40 / 50$ & 4.8 & 48.0 & 4.60 & 4.10 \\
\hline $2-1$ & Crushed stone & $\mathrm{C} 40 / 50$ & 4.6 & 44.0 & 5.00 & 4.10 \\
\hline $2-2$ & Crushed stone & $\mathrm{C} 40 / 50$ & 4.6 & 44.0 & 4.60 & 4.00 \\
\hline $2-3$ & Crushed stone & $\mathrm{C} 40 / 50$ & 4.6 & 44.0 & 4.40 & 4.00 \\
\hline $2-4$ & Crushed stone & $\mathrm{C} 40 / 50$ & 4.6 & 44.0 & 4.40 & 3.80 \\
\hline $2-5$ & Crushed stone & $\mathrm{C} 40 / 50$ & 4.6 & 44.0 & 4.40 & 3.50 \\
\hline $2-6$ & Crushed stone & $\mathrm{C} 40 / 50$ & 4.6 & 44.0 & 4.20 & 4.00 \\
\hline $2-7$ & Crushed stone & $\mathrm{C} 40 / 50$ & 4.6 & 44.0 & 4.20 & 3.80 \\
\hline $2-8$ & Crushed stone & $\mathrm{C} 40 / 50$ & 4.6 & 44.0 & 4.20 & 3.50 \\
\hline $3-1$ & $\begin{array}{l}\text { Hydraulically } \\
\text { bound base layer }\end{array}$ & C30/37 & 3.7 & 41.0 & 4.60 & 4.10 \\
\hline $3-2$ & $\begin{array}{l}\text { Hydraulically } \\
\text { bound base layer }\end{array}$ & C35/45 & 4.0 & 42.0 & 4.60 & 4.10 \\
\hline $3-3$ & $\begin{array}{l}\text { Hydraulically } \\
\text { bound base layer }\end{array}$ & $\mathrm{C} 40 / 50$ & 4.6 & 44.0 & 4.60 & 4.10 \\
\hline $3-4$ & $\begin{array}{l}\text { Hydraulically } \\
\text { bound base layer }\end{array}$ & $\mathrm{C} 40 / 50$ & 4.7 & 46.0 & 4.60 & 4.10 \\
\hline $3-5$ & $\begin{array}{l}\text { Hydraulically } \\
\text { bound base layer }\end{array}$ & $\mathrm{C} 40 / 50$ & 4.8 & 48.0 & 4.60 & 4.10 \\
\hline
\end{tabular}

Note: 1-1 design inputs of the reference concrete pavement structure used to determine the effect of variables. 


\section{Result analysis and interpretation}

The analysis and application of the RDO Beton 09 concrete pavement design method allowed comprehending the concrete mechanical properties, the influence of the base layer and slab dimension on the nominal thickness of concrete. The designed concrete slab thickness and the determined $M_{E}$ and $M_{R}$ are presented in Tables 9 and 10, respectively. The relation between boundary conditions design and limit (threshold) bending moments are presented in Figure 6. For the comparison of results, the concrete slab of $\mathrm{C} 30 / 37$ with dimensions $4.60 \times 4.10 \mathrm{~m}$ (design code No. 1-1) was selected as the reference slab since those slabs are typically used for road pavement.

The first analysis step was to determine the effect of mechanical properties on the concrete slab thickness (design code 1-1...1-5), where the dimensions of the slab were fixed and the tensile splitting strength $\left(f_{c t k}\right)$ and tensile elastic modulus $\left(E_{c t m}\right)$ were varied. The effect of concrete mechanical properties on slab thickness is presented in Figure 7. The calculation results showed that the increase in $f_{c t k}$ from $3.7 \mathrm{MPa}$ to 4.8 $\mathrm{MPa}$ allowed decreasing the nominal slab thickness by $15.5 \%$, from $264 \mathrm{~mm}$ to $223 \mathrm{~mm}$.

Then the effect of slab dimensions on the concrete slab thickness was investigated (design code 2-1...2-8), where the length $(L)$ and width $(W)$ of the slab were variable and mechanical properties were fixed (Table 9). The length and width ratio varied from 1.05 to 1.26 . The effect of slab dimension on the design slab thickness is presented in Figure 8. The results showed that the change in slab width had the most significant effect on the nominal thickness of concrete slab. The lowest thickness of concrete slab $218 \mathrm{~mm}$ was determined for the slabs of $4.4 \times 3.5 \mathrm{~m}$ and $4.2 \times 3.5 \mathrm{~m}$, which had the highest $L / W$ ratio of 1.26 and 1.2 . The suggested optimal PCP slab dimensions for roads are $4.6 \mathrm{~m}$ in length and $4.0 \mathrm{~m}$ in width with $227 \mathrm{~mm}$ concrete slab thickness.

Also, the base layer influence was analysed by comparing the designed nominal thickness of concrete slab determined under crushed stone aggregate (unbound) base layer (design code 1-1...1-5) and HBBL (design code 3-1...3-5). This analysis was carried out for the fixed dimensions of the slab and varied the tensile splitting strength $\left(f_{c t k}\right)$ and elastic modulus $\left(E_{c t m}\right)$. The comparison of base layer type with design slab thickness is presented in Figure 9. A positive result of HBBL was only determined for No. 3-1, where the nominal thickness of concrete slab was $2.7 \%$ less compared to the crushed stone aggregate base layer. Other design results showed the increased thickness of concrete slab by 1.1-2.3\%. According to Bradbury (1938), curling and warping stress analysis, the stiffer base material leads to smaller relative stiffness $l$, and 
likewise, a higher $L / l$ ratio for the same joint spacing and higher curling stress. According to the literature and design results, the use of stiffer base layers and thinner concrete slab shall be correspondently adjusted to the joint spacing; otherwise, it may lead to the cracking of HBBL layer due to curling and warping.
Audrius Vaitkus, Rita Kleizienè, Viktoras Vorobjovas, Donatas Čygas

Mixture Strength

Class and Slab Dimensions' Effect on the Precast

Concrete Pavement Structural

Performance

Table 9. The limit (threshold) bending moments for design concrete slabs

\begin{tabular}{|c|c|c|c|c|c|c|c|}
\hline \multirow{2}{*}{$\begin{array}{l}\text { Design } \\
\text { code }\end{array}$} & \multirow{2}{*}{$\begin{array}{c}\text { Nominal } \\
\text { thickness } \\
\text { of concrete } \\
\text { pavement, mm }\end{array}$} & \multicolumn{6}{|c|}{ Limit (threshold) bending moment $M_{R}, \mathrm{Nmm} / \mathrm{mm}$} \\
\hline & & $M_{E, B C B, L}$ & $M_{E, B C B C, T}$ & $M_{E, B C P C, L}$ & $M_{E, B C P C, T}$ & $M_{E, F, L}$ & $M_{E, F, T}$ \\
\hline $1-1$ & 264 & 40023 & 40023 & 43065 & 43065 & 28447 & 24206 \\
\hline $1-2$ & 251 & 39112 & 39112 & 42085 & 42085 & 27800 & 23655 \\
\hline $1-3$ & 229 & 37440 & 37440 & 40285 & 40285 & 26611 & 22644 \\
\hline $1-4$ & 226 & 37258 & 37258 & 40090 & 40090 & 26482 & 22534 \\
\hline $1-5$ & 223 & 37047 & 37047 & 39863 & 39863 & 26332 & 22406 \\
\hline $2-1$ & 229 & 37440 & 37440 & 40285 & 40285 & 26611 & 22644 \\
\hline $2-2$ & 227 & 36789 & 36789 & 39585 & 39585 & 26148 & 22250 \\
\hline $2-3$ & 227 & 36789 & 36789 & 39585 & 39585 & 26148 & 22250 \\
\hline $2-4$ & 223 & 35504 & 35504 & 38202 & 38202 & 25235 & 21473 \\
\hline $2-5$ & 218 & 33929 & 33929 & 36508 & 36508 & 23348 & 20412 \\
\hline $2-6$ & 227 & 36789 & 36789 & 39585 & 39585 & 25315 & 22132 \\
\hline $2-7$ & 223 & 35504 & 35504 & 38202 & 38202 & 24431 & 21359 \\
\hline $2-8$ & 218 & 33929 & 33929 & 36508 & 36508 & 23348 & 20412 \\
\hline $3-1$ & 257 & 37929 & 37929 & 40812 & 40812 & 26959 & 22940 \\
\hline $3-2$ & 257 & 41004 & 41004 & 44121 & 44121 & 29145 & 24800 \\
\hline $3-3$ & 232 & 38427 & 38427 & 41348 & 41348 & 27313 & 23241 \\
\hline $3-4$ & 230 & 38588 & 38588 & 41521 & 41521 & 27427 & 23339 \\
\hline $3-5$ & 227 & 38388 & 38388 & 41306 & 41306 & 27285 & 23217 \\
\hline
\end{tabular}


Table 10. The design bending moments for design concrete slabs

\begin{tabular}{|c|c|c|c|c|c|c|c|}
\hline \multirow{2}{*}{$\begin{array}{l}\text { Design } \\
\text { code }\end{array}$} & \multirow{2}{*}{$\begin{array}{c}\text { Nominal } \\
\text { thickness } \\
\text { of concrete } \\
\text { pavement, mm }\end{array}$} & \multicolumn{6}{|c|}{ Design bending moment $M_{E}, \mathrm{Nmm} / \mathrm{mm}$} \\
\hline & & $M_{E, B C B, L}$ & $M_{E, B C B C, T}$ & $M_{E, B C P C, L}$ & $M_{E, B C P C, T}$ & $M_{E, F, L}$ & $M_{E, F, T}$ \\
\hline $1-1$ & 264 & 29117 & 29145 & 20411 & 20143 & 23265 & 24114 \\
\hline $1-2$ & 251 & 28320 & 28406 & 19910 & 19724 & 22612 & 23541 \\
\hline $1-3$ & 229 & 26902 & 27079 & 19030 & 18979 & 21455 & 22514 \\
\hline $1-4$ & 226 & 26811 & 27010 & 18987 & 18965 & 21404 & 22454 \\
\hline $1-5$ & 223 & 26713 & 26932 & 18938 & 18944 & 21343 & 22387 \\
\hline $2-1$ & 229 & 28312 & 27079 & 20440 & 18979 & 22588 & 22514 \\
\hline $2-2$ & 227 & 26755 & 26643 & 18938 & 18603 & 21332 & 22111 \\
\hline $2-3$ & 227 & 26100 & 26643 & 18283 & 18603 & 20772 & 22111 \\
\hline $2-4$ & 223 & 25814 & 25806 & 18109 & 17886 & 20539 & 21341 \\
\hline $2-5$ & 218 & 25450 & 24697 & 17888 & 16930 & 20242 & 20317 \\
\hline $2-6$ & 227 & 25474 & 26643 & 17657 & 18603 & 20194 & 22111 \\
\hline $2-7$ & 223 & 25199 & 25806 & 17494 & 17886 & 19987 & 21341 \\
\hline $2-8$ & 218 & 24849 & 24697 & 17287 & 16930 & 19717 & 20317 \\
\hline $3-1$ & 257 & 27727 & 27087 & 20375 & 19481 & 20953 & 22861 \\
\hline $3-2$ & 257 & 27789 & 27155 & 20420 & 19533 & 21413 & 24766 \\
\hline $3-3$ & 232 & 26081 & 25600 & 19240 & 18551 & 19263 & 23231 \\
\hline $3-4$ & 230 & 26043 & 25584 & 19219 & 18555 & 19763 & 23257 \\
\hline $3-5$ & 227 & 25923 & 25491 & 19141 & 18509 & 20109 & 23200 \\
\hline
\end{tabular}




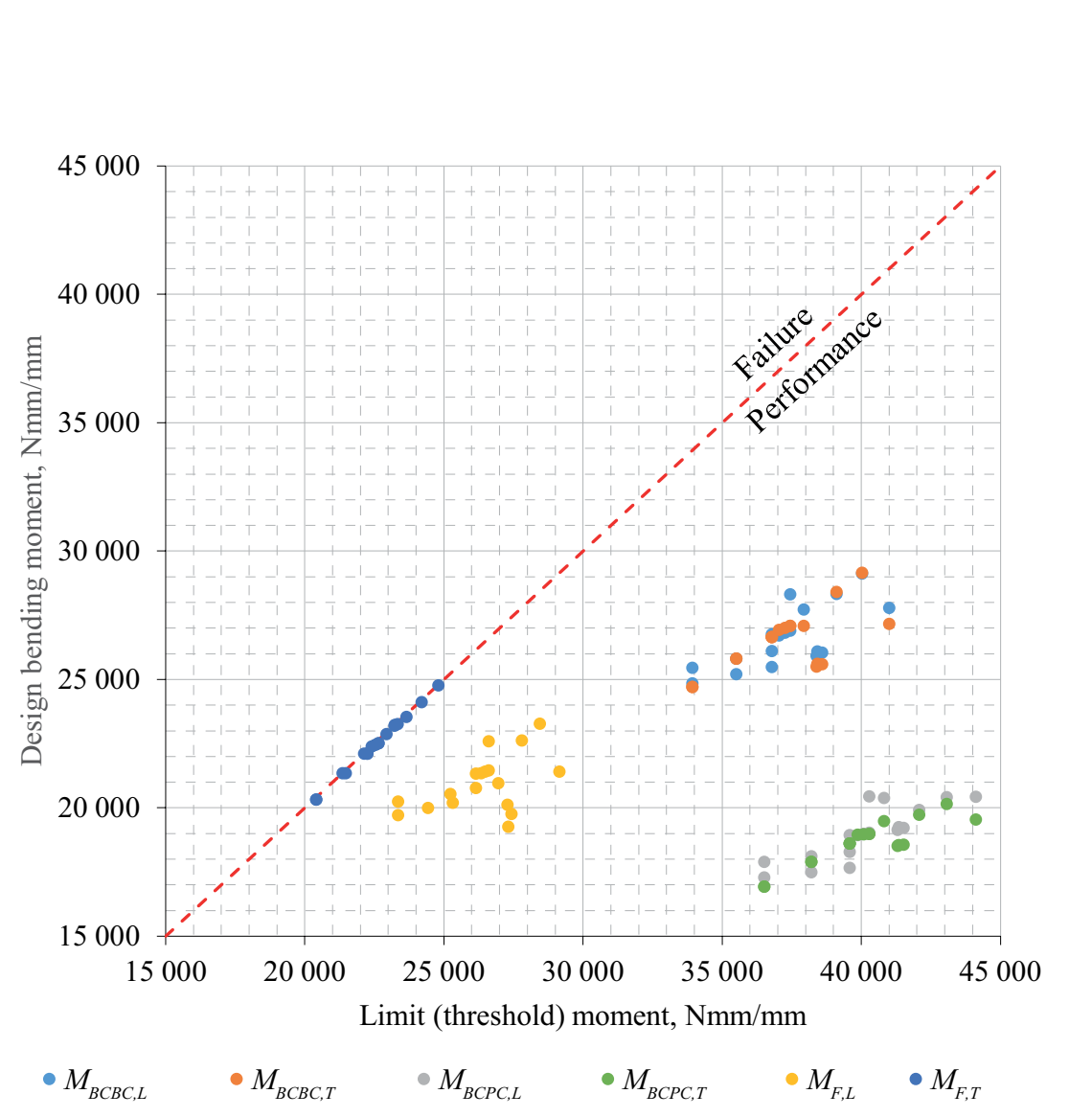

Audrius Vaitkus,

Rita Kleizienè,

Viktoras Vorobjovas,

Donatas Čygas

Mixture Strength

Class and Slab

Dimensions' Effect

on the Precast

Concrete Pavement

Structural

Performance

Figure 6. The relation between boundary conditions design and limit (threshold) bending moments

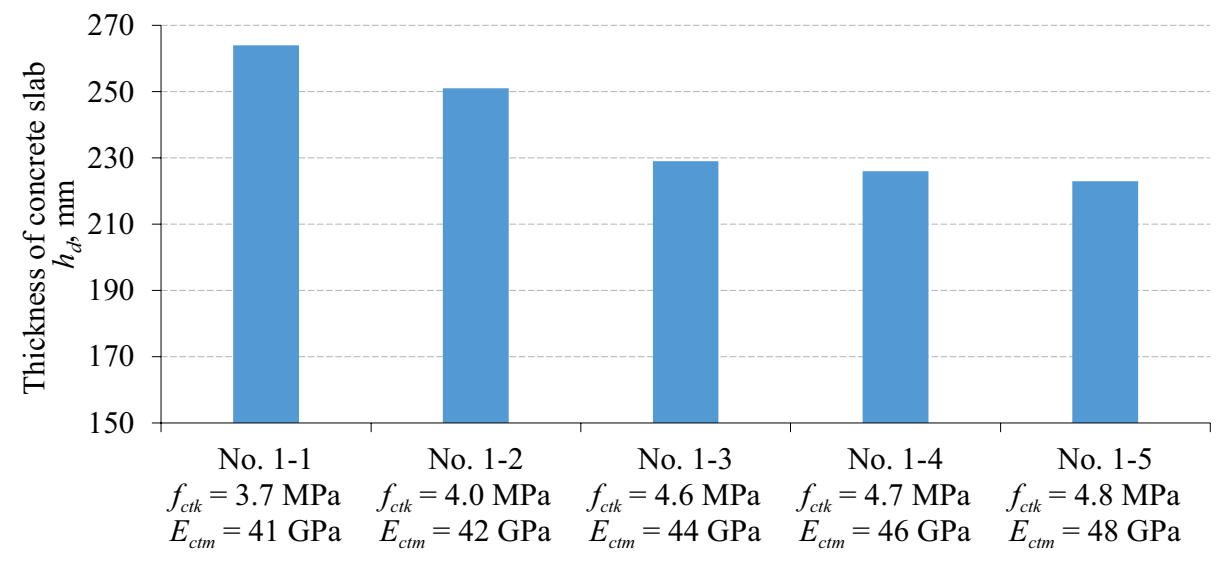

Figure 7. The effect of concrete mechanical properties on slab thickness 


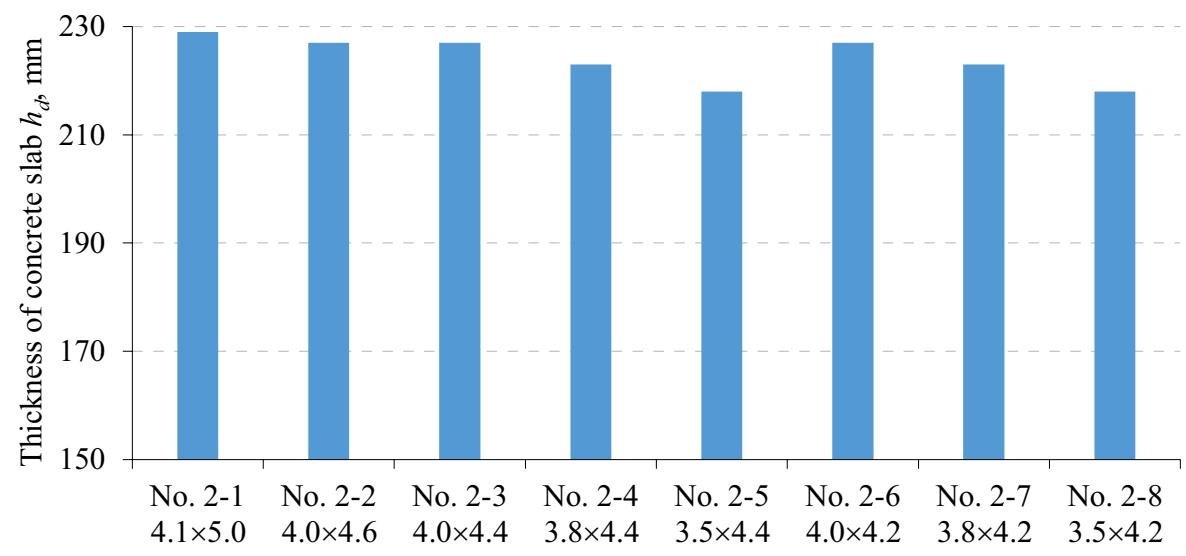

Note: length $\times$ width, in meters

Figure 8. The effect of slab dimension on design slab thickness

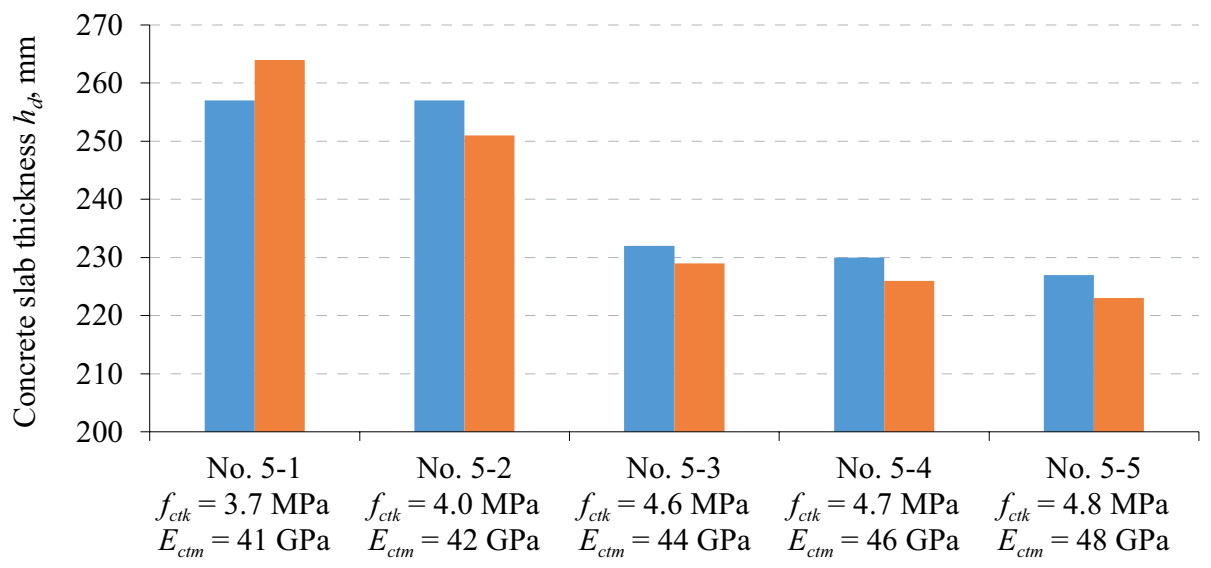

- Hydraulically bound base layer $\square$ Crushed aggregate base layer

Figure 9. The comparison of base layer type with design slab thickness 


\section{Conclusions}

Analytical analysis based on semi-probabilistic analysis of bending moments let to define the minimal thickness of precast concrete pavement dependent on slab dimensions and mixture strength. Summarising the results of concrete pavement modelling, the following conclusions were drawn:

1. The fatigue bending moment of the transverse joint is a critical boundary condition evaluating precast concrete pavement structural performance. Depending on precast concrete pavement mixture properties and pavement base layer type the fatigue bending moment in the centre of transverse joint differs from $20412 \mathrm{Nmm} / \mathrm{mm}$ to $24800 \mathrm{Nmm} / \mathrm{mm}$.

2. The increase of tensile splitting strength from $3.7 \mathrm{MPa}$ to $4.8 \mathrm{MPa}$ lets to reduce the precast concrete pavement concrete slab thickness by 15.5\%, from $264 \mathrm{~mm}$ to $222 \mathrm{~mm}$, i.e. the difference of $42 \mathrm{~mm}$. However, an increase of tensile splitting strength from 4.6 MPa to 4.8 $\mathrm{MPa}$ effect slab thickness very slightly.

3. The minimum thickness of precast concrete pavement slab (218 $\mathrm{mm}$ ) was determined for the dimensions (length $\times$ width) of $4.4 \times 3.5 \mathrm{~m}$ and $4.2 \times 3.5 \mathrm{~m}$. Considering standard $3.5 \mathrm{~m}$ width of the traffic lane and the impact of the wheel to pavement by distance from joint, the dimensions of the optimal precast concrete pavement slab are $4.6 \times 4.0 \mathrm{~m}$ with $227 \mathrm{~mm}$ thickness. The cement concrete C40/50 with tensile splitting strength (equal to $4.6 \mathrm{MPa}$ ) and the tensile elastic modulus (equal to $44 \mathrm{GPa}$ ) can be specified as optimal. Further increase of these mechanical properties does not affect the slab thickness.

4. The thickness of precast concrete pavement slab $(4.6 \times 4.1 \mathrm{~m}$ and C30/37 class standard concrete) with the hydraulically bound base layer allowed to reduce the nominal thickness of concrete slab by $2.7 \%$ (257 $\mathrm{mm}$ ) compared to the crushed aggregate base. However, stiffer cement concrete mixture of precast concrete pavement has the opposite effect on the slab thickness with the hydraulically bound base layer. The analysis showed that optimal dimensions of precast concrete pavement slab with unbound crushed aggregate base layer provide more reliable performance than with the hydraulically bound base layer.

\section{Acknowledgement}

This project has received funding from the European Regional Development Fund (project No 01.2.2-LMT-K-718-01-0044) under grant agreement with the Research Council of Lithuania (LMTLT).
Mixture Strength

Class and Slab

Dimensions' Effect on the Precast

Concrete Pavement

Structural

Performance 


\section{REFERENCES}

AC 150/5320-6F Airport Pavement Design and Evaluation

American Association of State Highway and Transportation Officials (AASHTO) (1993). Guide for Design of Pavement Structures.

American Association of State Highway and Transportation Officials (AASHTO) (2008). Mechanistic-Empirical Pavement Design Guide. A Manual of Practice.

American Association of State Highway and Transportation Officials (AASHTO) (2015). Mechanistic-Empirical Pavement Design Guide-A Manual of Practice.

American Concrete Institute Committee 325 (2002). Guide for design of jointed concrete pavements for streets and local roads.

Bradbury, R. D. (1938). Reinforced Concrete Pavements. Washington, DC.

Breyer, G., \& Kurzfassung, W. (2004). Entscheidungskriterien für den Bau von Betonfahrbahndecken in Österreich. Bet ónov é vozovky 2007 Betonfahrbahndecken 2007, 23. (in German)

Chang, C. M., Baladi, G. Y., \& Wolff, T. F. (2001). Using pavement distress data to assess impact of construction on pavement performance. Transportation research record, 1761(1), 15-25. https://doi.org/10.3141/1761-03

Darter, M. I., Hall, K. T., \& Kuo, C. M. (1995). Support under Portland cement concrete pavements (No. Project 1-30 FY'93)

Delatte, N. (2008). Concrete Pavement Design, Construction, and Performance. London, UK: Taylor \& Francis Group.

Disfani, M. M., Arulrajah, A., Haghighi, H., Mohammadinia, A., \& Horpibulsuk, S. (2014). Flexural beam fatigue strength evaluation of crushed brick as a supplementary material in cement stabilized recycled concrete aggregates. Construction and Building Materials, 68, 667-676. https://doi.org/10.1016/j.conbuildmat.2014.07.007

EN 12390-6 Testing hardened concrete - Part 6: Tensile splitting strength of test specimens.

EN 206 Concrete - Part 1: Specifications, performance, production and conformity.

Federal Highway Administration (2019). Technical Advisory: Concrete Pavement Joints (Vol. T 5040.30). Washington DC.

Goel, S., Singh, S. P., \& Singh, P. (2012). Flexural fatigue strength and failure probability of self compacting fibre reinforced concrete beams. Engineering Structures, 40, 131-140. https://doi.org/10.1016/j.engstruct.2012.02.035

Graeff, A. G., Pilakoutas, K., Neocleous, K., \& Peres, M. V. N. (2012). Fatigue resistance and cracking mechanism of concrete pavements reinforced with recycled steel fibres recovered from post-consumer tyres. Engineering Structures, 45, 385-395.

Hesami, S., Ahmadi, S., \& Nematzadeh, M. (2014). Effects of rice husk ash and fiber on mechanical properties of pervious concrete pavement. Construction and Building Materials, 53, 680-691. https://doi.org/10.1016/j.conbuildmat.2013.11.070

Huang, B., Wu, H., Shu, X., \& Burdette, E. G. (2010). Laboratory evaluation of permeability and strength of polymer-modified pervious 
concrete. Construction and Building Materials, 24(5), 818-823. https://doi.org/10.1016/j.conbuildmat.2009.10.025

Ibrahim, A., Mahmoud, E., Yamin, M., \& Patibandla, V. C. (2014). Experimental study on Portland cement pervious concrete mechanical and hydrological properties. Construction and Building Materials, 50, 524-529. https://doi.org/10.1016/j.conbuildmat.2013.09.022

Isaia, G. C., Gastaldini, A. L. G., \& Moraes, R. (2003). Physical and pozzolanic action of mineral additions on the mechanical strength of high-performance concrete. Cement and concrete composites, 25(1), 69-76. https://doi.org/10.1016/S0958-9465(01)00057-9

Jalal, M., Pouladkhan, A., Harandi, O. F., \& Jafari, D. (2015). Comparative study on effects of Class F fly ash, nano silica and silica fume on properties of high performance self compacting concrete. Construction and Building Materials, 94, 90-104. https://doi.org/10.1016/j.conbuildmat.2015.07.001

Jung, Y. S., \& Zollinger, D. G. (2007). Design and Construction Transition Guidelines for Concrete Pavement. Texas Transportation Institute, Texas A \& M University System.

Khazanovich, L., Darter, M. I., \& Yu, H. T. (2004). Mechanistic-empirical model to predict transverse joint faulting. Transportation Research Record, 1896(1), 34-45. https://doi.org/10.3141/1896-04

Klcriber, F. W. (1982). The Effects of Air Content, Water-Cement Ratio, and Aggregate Type on the Flexural Fatigue Strength of Plain Concrete. Special Publication, 75, 111-132. https://doi.org/10.14359/6403

Kleizienė, R., Vaitkus, A., \& Čygas, D. (2012). The Analysis of Concrete Pavement Application Possibilities for Road Pavement Structures. The XXVIII International Baltic Road Conference, 27-30 August 2017 in Tallinn, Estonia, $9 \mathrm{p}$.

Kohler, E., du Plessis, L., Smith, P. J., Harvey, J., \& Pyle, T. (2007, November). Precast concrete pavements and results of accelerated traffic load test. In International Conference on Optimizing Paving Concrete Mixtures and Accelerated Concrete Pavement Construction and Rehabilitation. Atlanta, Georgia.

Kosmatka, S. H., Kerkhoff, B., \& Panarese, W. C. (2002). Design and control of concrete mixtures (Vol. 5420, pp. 60077-1083). Skokie, IL: Portland Cement Association.

KPT SDK 19 Automobiliu keliu standartizuotu dangu konstrukciju projektavimo taisyklès. Lietuvos automobilių kelių direkcija prie Susisiekimo Ministerijos (LAKD) (in Lithuanian)

Li, H., Zhang, M. H., \& Ou, J. P. (2007). Flexural fatigue performance of concrete containing nano-particles for pavement. International Journal of fatigue, 29(7), 1292-1301. https://doi.org/10.1016/j.ijfatigue.2006.10.004

Mai, S. H., Le-Corre, F., Forêt, G., \& Nedjar, B. (2012). A continuum damage modeling of quasi-static fatigue strength of plain concrete. International Journal of Fatigue, 37, 79-85. https://doi.org/10.1016/j.ijfatigue.2011.10.006

Mallick, R. B., \& El-Korchi, T. (2013). Pavement engineering: principles and practice. CRC Press.
Audrius Vaitkus,

Rita Kleizienè,

Viktoras Vorobjovas,

Donatas Čygas

Mixture Strength

Class and Slab

Dimensions' Effect

on the Precast

Concrete Pavement

Structural

Performance 
Naik, T. R., Ramme, B. W., \& Tews, J. H. (1994). Use of high volumes of class C and class F fly ash in concrete. Cement, Concrete and Aggregates, 16(1), 12-20. https://doi.org/10.1520/CCA10556J

Naik, T. R., Ramme, B. W., Kraus, R. N., \& Siddique, R. (2003). Long-Term Performance of High-Volume Fly Ash. ACI Materials Journal, 100(2), 150-155.

Nazari, A., \& Riahi, S. (2012). The effects of SnO2 nanoparticles on physical and mechanical properties of high-strength self-compacting concrete. Journal of Experimental Nanoscience, 7(5), 559-577. https://doi.org/10.1080/17458080.2010.543991

Nehdi, M., Pardhan, M., \& Koshowski, S. (2004). Durability of self-consolidating concrete incorporating high-volume replacement composite cements. Cement and Concrete Research, 34(11), 2103-2112. https://doi.org/10.1016/j.cemconres.2004.03.018

Phoo-ngernkham, T., Chindaprasirt, P., Sata, V., Hanjitsuwan, S., \& Hatanaka, S. (2014). The effect of adding nano-SiO2 and nano-Al2O3 on properties of high calcium fly ash geopolymer cured at ambient temperature. Materials \& Design, 55, 58-65. https://doi.org/10.1016/j.matdes.2013.09.049

Rangelov, M., Nassiri, S., Haselbach, L., \& Englund, K. (2016). Using carbon fiber composites for reinforcing pervious concrete. Construction and Building Materials, 126, 875-885. https://doi.org/10.1016/j.conbuildmat.2016.06.035

Richtlinien für die rechnerische Dimensionierung von Betondecken im Oberbau von Verkehrsflächen RDO Beton 09 (in German)

Shannag, M. J. (2000). High strength concrete containing natural pozzolan and silica fume. Cement and concrete composites, 22(6), 399-406. https://doi.org/10.1016/S0958-9465(00)00037-8

Smith, K. D., Peshkin, D. G., Darter, M. I., Mueller, A. L., \& Carpenter, S. H. (1990). Performance of Jointed Concrete Pavements, Volume I, Evaluation of Concrete Pavement Performance aned Design Features. Federal Highway Administration, Report No. FHWA-RD-89-136, Washington, DC.

Smith, P., \& Snyder, M. B. (2017). Manual for jointed precast concrete pavement.

STR 2.05.05:2005 Betoniniu ir gelžbetoniniu konstrukciju projektavimas (in Lithuanian)

Tayabji, S., \& Tyson, S. (2014). Precast concrete pavement innovations, performance and best practices. Concrete International, 39(4), 41-46.

Tayabji, S., Ye, D., \& Buch, N. (2013). Precast concrete pavement technology. Transportation Research Board. https://doi.org/10.17226/22710

Tayabji, S., Ye, D., \& Buch, N. (2013). Precast concrete pavements: Technology overview and technical considerations. PCI journal, 58(1). https://doi.org/10.15554/pcij.01012013.112.128

TL Beton-StB 07 Technische Lieferbedingungen für Baustoffe und Baustoffgemische für Tragschichten mit hydraulischen Bindemitteln und Fahrbahndecken aus Beton (in German)

Vaitkus, A., Gražulytė, J., Kleizienè, R., Vorobjovas, V., \& Šernas, 0. (2019). Concrete Modular Pavements-Types, Issues and Challenges. The Baltic Journal of Road and Bridge Engineering, 14(1), 80-103. https://doi.org/10.7250/bjrbe.2019-14.434 
Villaret, S., Kiehne, A., Riwe, A., \& Villaret, K. (2008). Entwicklung eines Finite Donatas Čyas Elemente Modells für die rechnerische Dimensionierung von Straßen gemäß RDO Beton. (in German)

Walls III, J., \& Smith, M. R. (1998). Life-cycle cost analysis in pavement design-interim technical bulletin (No. FHWA-SA-98-079)

Wojtkiewicz, S. F., Khazanovich, L., Gaurav, G., \& Velasquez, R. (2010).

Mixture Strength

Class and Slab

Dimensions' Effect on the Precast

Concrete Pavement

Structural

Probabilistic numerical simulation of pavement performance

Performance using MEPDG. Road Materials and Pavement Design, 11(2), 291-306. https://doi.org/10.1080/14680629.2010.9690277

Wood, S. L. (1992). Evaluation of the long-term properties of concrete. Skokie: Portland Cement Association

Zanuy, C., de la Fuente, P., \& Albajar, L. (2007). Effect of fatigue degradation of the compression zone of concrete in reinforced concrete sections. Engineering structures, 29(11), 2908-2920. https://doi.org/10.1016/j.engstruct.2007.01.030

ZTV Beton-StB 07 Zusätzliche Technische Vertragsbedingungen und Richtlinien für den Bau von Tragschichten mit hydraulischen Bindemitteln und Fahrbahndecken aus Beton (in German) 